\title{
In vitro gas production parameters of chickpea (Cicer arietinum L.) by-product
}

E Abdi Ghezeljeh, M Danesh Mesgaran

Department of Animal Science Excellence Centre for Animal Science, Ferdowsi University of Mashhad, Mashhad, Islamic Republic of Iran

Email: E_abdi2005@yahoo.com

Introduction Chickpea (Cicer arietinum L.) is a legume seed, which is mostly used for human food. Approximately 7500 ton wastes of chickpea including pre-screening seeds and chickpea bran (known as chickpea by-product) are produced annually in North West Iran. The aim of the present study was to determine chemical composition and in vitro gas production parameters of chickpea by-product.

Material and methods Samples of chickpea by-product including pre-screening seeds and chickpea bran were collected from chickpea sorting factories located in North West Iran during September to December, 2008. Chemical composition including organic matter $(\mathrm{OM})$, crude protein $(\mathrm{CP})$, ether extract $(\mathrm{EE})$ and crude fibre $(\mathrm{CF})$ were determined using standard procedures (AOAC, 1995). Neutral detergent fibre (NDF) and acid detergent fibre (ADF) were determined using the method of Van Soest et al. (1991). Total extractable phenolic compounds (TPC) and total tannin (TT) were determined using procedures of Julkunen-Titto (1985) and Makkar(1992), respectively. Three fistulated Balochi sheep (49.5 $\pm 2.5 \mathrm{~kg}$ ) were used as rumen liquor donor for gas production technique. The animals were fed $1 \mathrm{~kg}$ DM lucerne hay and $0.3 \mathrm{~kg}$ DM concentrate (165 g CP/kg of DM). Rumen fluid was collected before the morning feeding and strained through 4 layers of cheesecloth into a $\mathrm{CO}_{2}$-filled flask. In vitro incubation of the samples was done using calibrated glass syringes followed the procedures of Menke and Steingass (1988). Approximately $200 \mathrm{mg}$ of each sample was weighed into four replicate calibrated glass syringes of $100 \mathrm{ml}$. The syringes were pre-warmed at $39{ }^{\circ} \mathrm{C}$ before the injection of $30 \mathrm{ml}$ rumen fluidbuffer mixture into each syringe followed by incubation in a water bath at $39{ }^{\circ} \mathrm{C}$. Readings of gas production were recorded at 2, 4, 8, 12, 24, 36, 48, 72, and $96 \mathrm{~h}$ after incubation. Cumulative gas production data were fitted to a model of $\mathrm{Y}=\mathrm{b}\left(1-\mathrm{e}^{-\mathrm{ct}}\right)$; where: $\mathrm{Y}=$ potential of gas production at time $\mathrm{t} ; \mathrm{b}=$ gas produced from the soluble and insoluble fraction (ml); $\mathrm{c}=$ gas production constant rate $(\mathrm{ml} / \mathrm{h}) ; \mathrm{t}=$ incubation time $(\mathrm{h})$. Data were statistically analyzed using SAS (1999) software.

Results Chemical composition of chickpea by-product is presented in Table 1. Results of the present study indicated the chemical composition, except OM, was significant different between the samples evaluated ( $\mathrm{P}<0.05)$. Gas production parameter and calculated amount of organic matter digestibility (OMO) and metabolizable energy (ME) are presented in Table 2. The amount of $\mathrm{b}$ and value calculated for OMD and ME of chickpea pre-screening were significantly higher than chickpea bran $(\mathrm{P}<0.01)$. Gas production rate constant of chickpea bran was significantly higher than chickpea prescreening $(\mathrm{P}<0.01)$.

Table 1 Chemical composition of chickpea by-product (g/kg DM)

\begin{tabular}{lllllllll}
\hline Chickpea by-product & OM & CP & EE & CF & NDF & ADF & TN & TPC \\
\hline Chickpea pre-screening & 940 & 279 & 78 & 72 & 351 & 96 & 1 & 3.4 \\
Chickpea bran & 927 & 44 & 87 & 178 & 323 & 224 & 6.5 & 7.5 \\
s.e.d & 6.2 & 5.4 & 1.4 & 2.4 & 6.6 & 10.1 & 0.55 & 0.75 \\
P & $>0.05$ & $<0.01$ & $<0.01$ & $<0.01$ & $<0.01$ & $<0.01$ & $<0.01$ & $<0.01$ \\
\hline
\end{tabular}

Table 2 Gas production parameters, organic matter digestibility $(\mathrm{OMD})^{*}$ and metabolizable energy $(\mathrm{ME}) * *$ content of chickpea by-product

\begin{tabular}{llll}
\hline Item & Chickpea pre-screening & Chickpea bran & $\mathrm{P}$ \\
\hline $\mathrm{b}(\mathrm{ml})$ & $66.4 \pm 2.42$ & $93.6 \pm 2.51$ & $<0.01$ \\
$\mathrm{c}(\mathrm{ml} / \mathrm{h})$ & $0.056 \pm 0.0052$ & $0.024 \pm 0.0023$ & $<0.01$ \\
$\mathrm{OMD}(\%)$ & $59.1 \pm 0.42$ & $42.1 \pm 1.5$ & $<0.01$ \\
$\mathrm{ME}(\mathrm{MJ} / \mathrm{kg})$ & $8.95 \pm 0.074$ & $6.5 \pm 0.2$ & $<0.01$ \\
\hline$* \mathrm{OMD}=0.9991 \mathrm{Gas}+0.0595 \mathrm{CP}+0.0181 \mathrm{CA}+9$ & $* * \mathrm{ME}=0.157 \mathrm{Gas}+0.0084 \mathrm{CP}+0.022 \mathrm{EE}-0.0081 \mathrm{CA}+1.06$
\end{tabular}

Conclusions Results obtained in the present study regarding the chemical composition of chickpea pre-screening confirmed the finding of Abdi and Danesh Mesgaran (2009). Values calculated for both ME and OMD of chickpea prescreening were significantly higher than those of chickpea bran $(\mathrm{P}<0.01)$, which might be due to difference in chemical composition and volume of gas production in the first $24 \mathrm{~h}$. It was concluded that the by-products evaluated in the present experiment had a potential to use as suitable feed in ruminant rations. However, future feeding trials will be proposed to evaluate the effect of this by-product in ruminant production.

\section{References}

Abdi Ghezeljeh, E. and Danesh Mesgaran, M. 2009. Proceedings of the British Society of Animal Science, 231.

AOAC, 1995. Official Methods of Analysis, $16^{\text {th }}$ ed. Gaithersburg, MD, USA.

Menke, K.H. and Steingass, H. 1988. Animal Research and Development, 28, 7-55.

SAS, 1999. Version release 8/0. SAS Institute INC, Cary, NC, USA.

Van Soest, P.J., Robertson, J.B. and Lewis, B.A. 1991. Journal Dairy Science. 74, 3583-3597. 